\title{
Ocular Surface Ophthalmoheliosis in a Region of Patagonia
}

\author{
María Fernanda Suárez ${ }^{1}$ and Horacio Marcelo Serra ${ }^{2 *}$ \\ ${ }^{1}$ Sackler School of Graduate Biomedical Sciences, Tufts University, USA \\ ${ }^{2}$ Department of Clinical Biochemistry, Universidad Nacional de Córdoba, Argentina
}

Submission: January 21, 2019; Published: February 05, 2019

*Corresponding author: Horacio M Serra, CIBICI, Faculty of Chemical Sciences, National University of Córdoba, Haya de la Torre esquina Medina Allende, PC 5000, Córdoba, Argentina

Abstract

The aim of this mini review is to describe the prevalence of Environmental Proteinaceous Corneal Degeneration (EPCD), pinguecula and pterygium and the association among them. We performed a transversal/observational study in individuals living all their lives in the El Cuy Department, province of Río Negro in the Argentinean Patagonia. The patients investigated were consecutive non-probabilistic. The prevalence of ophthalmoheliosis was 34\% of pinguecula, followed by $30 \%$ of EPCD and $12 \%$ of pterygium. A statistically significant association was found between EPCD and male patients $(p<0.05)$. There was association between EPCD with pinguecula and with pterygium, both more frequent in males ( $\mathrm{p}<0.05)$. Our investigation shows important prevalence of EPCD, pinguecula and pterygium in individuals that live at this region of the Argentine Patagonia. As far as we know, this is the first work in the world that shows coexistences between these three ophthalmoheliosis.

Keywords: Environmental proteinaceous corneal degeneration; Pterygium; Pinguecula; Argentina

\section{Introduction}

The term helioses derives from the Greek root "hēlíosis" which means excessive exposure to sunlight, a mixture of radiation with wavelengths ranging from $200 \mathrm{~nm}$ to $4000 \mathrm{~nm}$, which comprises Ultraviolet Radiation (UVR), visible light and infrared light [1]. UVR has been found to reach diverse ocular components and is strongly absorbed by the anterior structures of the eye [2]. The cornea absorbs UVR differentially, based on the incident wavelength. More than $90 \%$ of UVR-C and UVR-B are absorbed by this ocular structure, as well as $60 \%$ of UVR-A [3], while the rest of the UVR-A is absorbed by the crystalline, with less than $1 \%$ reaching the retina [4]. Absorbed UVR is an important source of stress for the ocular surface through direct photo-oxidation (or type I). Also, indirect photo-oxidation (type II) can occur and produce Reactive Oxygen Species (ROS), which damage protein, lipids and cellular DNA [5-8].

There are different eye diseases associated with harmful exposure to UV light without adequate eye protection, known as ophthalmoheliosis. Among them, we can mention three degenerative diseases of the ocular surface: Climatic Droplet Keratopathy (CDK), pinguecula and pterygium. These diseases with still elusive etiology but with possibly multifactorial origin are frequently found in rural environments with high insolation. CDK is a rare acquired, bilateral degenerative disease of the cornea, which is highly prevalent in certain rural communities exposed to harsh weather conditions, that evolves through three different degrees of severity, leading to severe visual compromise as the result of corneal opacification [9]. As CDK is not specifically associated to weather, but to certain environmental conditions, we have proposed to name it Environmental Proteinaceous Degenerative of the Cornea" (EPCD) [10]. Current revisions on advances of molecular mechanisms involved in EPCD and pterygium have been published by Serra [11] and by CardenasCantu [12].

Pinguecula is a yellowish globular or flat benign conjunctival growth, near the corneal limbus in the interpalpebral fissure, produced by the alteration of the underlying connective tissue $[13,14]$. Although there is some evidence of its development upon exposure to sunlight [15], its pathogenesis is ignored. In some patients, it seems to be a precursor of a pterygium [16]. Even though the prevalence of one or more of these distinct ophthalmoheliosis have been studied in different parts of the world, as far as we know the co-existence of these degenerative diseases of the ocular surface has not yet reported. The purpose of this mini review is to present the prevalence of EPCD, pinguecula and pterygium and associations among them, in individuals who lived their entirely life in the Argentinean Patagonia.

\section{Participants and Results}

Our studies were approved by the Council for Ethical Research Evaluation of the government of the Province of Cordoba, Argentina, and registered in the Provincial Registry 
for Investigation in Health, Province of Cordoba. All studies adhered to Helsinki declaration. The studies (non-probabilistic consecutive, transversal / observational) were conducted in El Cuy Department, Province of Río Negro, Argentina. In this area of $11,281 \mathrm{~km} 2$, at 750 meters above sea level between 38 $56^{\prime}$ - 40 $25^{\prime}$ of south latitude and 67ㅇ 54' - 69o 04' west longitude. According to the last census, 2,329 inhabitants live (1,311 males and 1,018 women. It is worth to mention that the sample size for this amount of population is equal to 71 individuals.

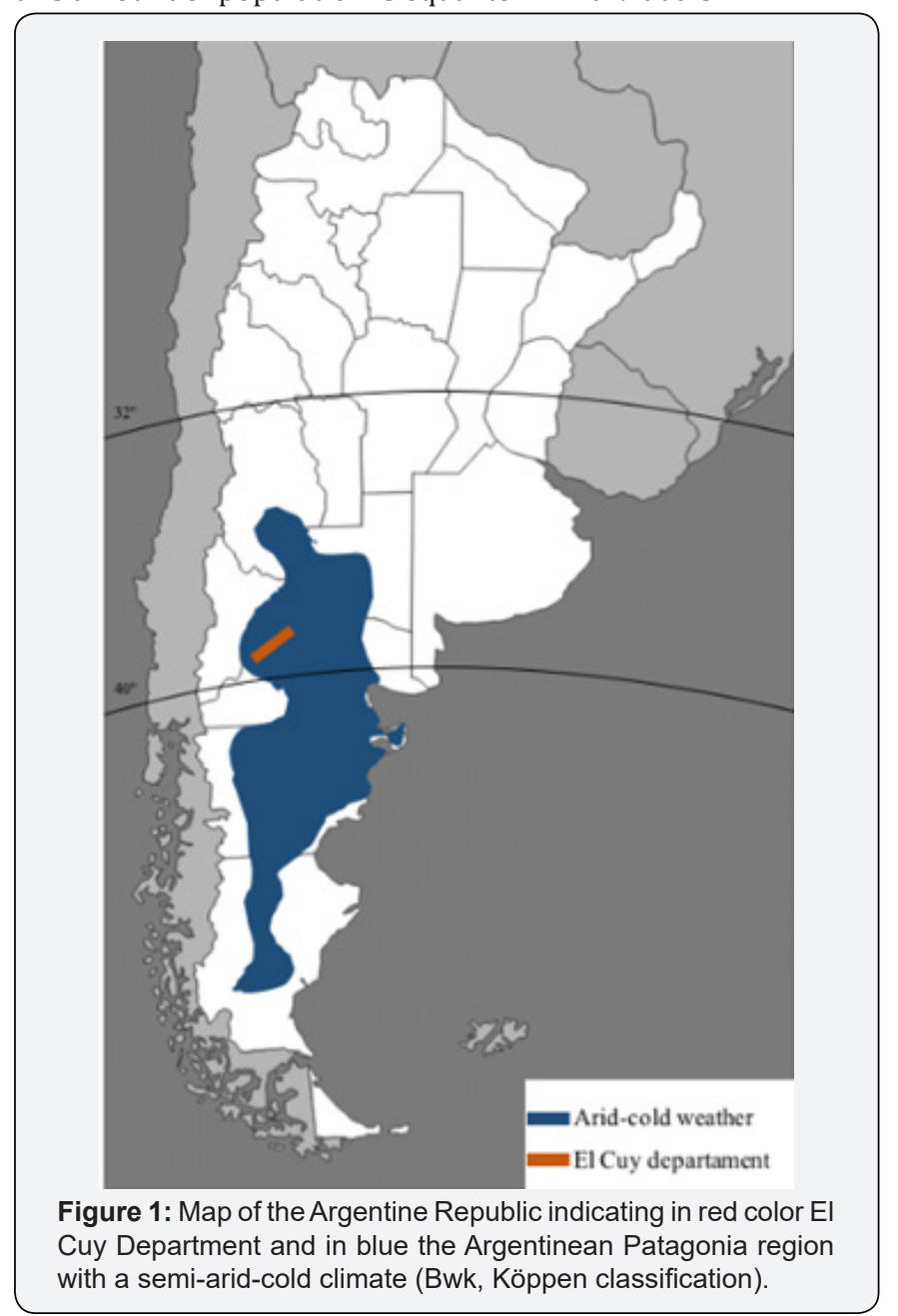

One hundred individuals ( $\geq 29$ years of age), who have lived their entire life in this region and agreed to participate in this study signing an informed consent were examined by ophthalmology specialist. All subjects underwent visual acuity testing with Snellen chart, or Landolt/E rings for illiterate individuals. Additionally, a detailed slit-lamp examination of the anterior segment (conjunctiva, cornea, anterior camera and iris) was done. Questions related to diet, work activity and the use of eye protection (sunglasses, hats) during lifetime were asked to all patients.

As depicted in Figure 1, El Cuy Department is $280 \mathrm{~km}$ from the border with Chile and $300 \mathrm{~km}$ away from the Atlantic Ocean. This region has a semi-arid weather (Bwk, Köppen classification) (http://koeppen-geiger.vu-wien.ac.at/shifts.htm) low shrubbery, annual rainfall lower than $190 \mathrm{~mm}$, constant strong winds, warm summers and cold winters, and great thermal amplitude between day and night. The annual range of temperature is between $4.6^{\circ} \mathrm{C}$ and $18.2^{\circ} \mathrm{C}$. Statistical studies of value comparison was made using Pearson and ANOVA tests. The level of statistical significance was set at $\mathrm{p} \leq 0.05$.

All participants in the study had always lived in the area previously described and there was no sex significant difference in the population investigated (data not shown). Table 1 presents the prevalence of pinguecula, EPCD, and pterygium, gender distribution and mean age \pm SD of the individuals studied. The highest prevalence corresponded to pinguecula (34\%), followed by EPCD (30\%) and pterygium (12\%). A significant statistical association was found between EPCD and patients' sex ( $p \leq 0.05)$, being it, more frequent in male $(24 \%)$ than in female patients (6\%). However, no statistical differences were found between pinguecula and pterygium when men and women were compared, as well as between the ages of men and women for any of the three diseases.

The mean ages were significantly different between patients with versus without EPCD, but there was neither significant difference in the mean age of patients with and without pinguecula, nor in individuals affected or not with pterygium.

Table 1: Prevalence of different ophthalmoheliosis in individual inhabiting a region of Argentinean Patagonia.

\begin{tabular}{|c|c|c|c|c|c|c|}
\hline & \multicolumn{2}{|c|}{ Pinguecula \% Age (Mean \pm SD) } & \multicolumn{2}{c|}{ EPCD \% Age (Mean \pm SD) } & \multicolumn{2}{c|}{ Pterygium \% Age (Mean \pm SD) } \\
\hline Male & $32 \%$ & $52.2 \pm 11.5$ & $24 \% *$ & $60.6 \pm 10.8$ & $8 \%$ & $58.4 \pm 8.7$ \\
\hline Female & $12 \%$ & $51.8 \pm 12.1$ & $6 \%$ & $54.4 \pm 11.4$ & $4 \%$ & $54.9 \pm 7.6$ \\
\hline Total & $34 \%$ & $52.5 \pm 11.8$ & $30 \%$ & $56.8 \pm 10.6$ & $12 \%$ & $56.5 \pm 8.5$ \\
\hline
\end{tabular}
${ }^{*} p \leq 0.05$.

Fifteen out of thirty patients with EPCD presented only this ophthalmoheliosis, 18 out of 34 patients with pinguecula had this disease, and 5 out of 12 individuals with pterygium had this degeneration of the ocular surface. Significant differences in the association of EPCD with pinguecula and EPCD with pterygium were found within the group of males $(p \leq 0.05)$. Pinguecula was more associated with EPCD than pterygium. Additionally, there were small number of patients who simultaneously had pinguecula and pterygium (Figure 2). We also analyzed the clinical records of patients that only presented pinguecula, and patients with pterygium at the time of the study, and we found that they had all had these pathologies at least in the last 10 years.

As regards lifestyle of the habitants of the studied region, the main occupation of the population was breeding and sheep shearing, and in some cases, wool processing and 
manufacturing. The main dietary habits of these individuals included the ingestion of ovine meat two or three times a day and small amounts of milk sporadically. Vegetables and fruit were exceptional in their diet. Patients also manifested that they drank mate infusion. As for eye protection, most did not wear hats or sunglasses.

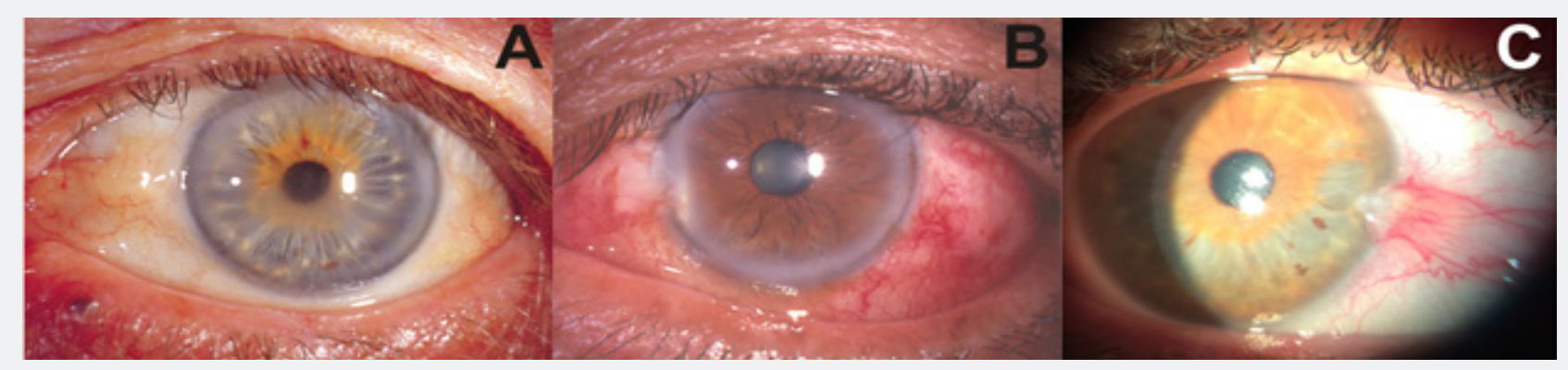

Figure 2: Combined ophthalmoheliosis. A) EPCD and pinguecula, B) Pterigium and pinguecula, C) EPCD and pterygium.

\section{Discussion}

In this work we studied the prevalence of EPCD, pinguecula, and pterygium, in a particular region of the Argentine Patagonian. We found a high prevalence of EPCD (30\%), coincidentally with previous observations [11]. Chronic inflammation and microtrauma of the ocular surface by soil dust carried by constant winds could be risk factors for EPCD. Additionally, EPCD patients are exposed throughout life to UVR-B as they work outside in that arid and shadeless region, not wearing eye protection (sunglasses or hats). UVR-B is primarily absorbed by means of electronic transitions of the peptides connection (190-220nm) and by the aromatic motives of tryptophan, tyrosine and phenylalanine $(250-300 \mathrm{~nm})$ residue, which take the partial folding and aggregation of proteins among which there are enzymes such as Aldehyde Dehydrogenase (ALDH) and glutathione peroxidase, which play an important role to control oxidative stress [17]. As EPCD patients have a partial deficiency of ascorbate (AA) [10] (an important antioxidant in the cornea) there is less absorption of UVR-B by the AA and greater generation of ROS. These free radicals start a chain reaction that results in the oxidation of poly-unsaturated lipid of the cell membranes (lipid peroxidation) with its quantitative and qualitative lipid alterations and generation of toxic and reactive aldehydes [18]. These molecules, in contrast to ROS, have a long life and induce more protein aggregates, which characterize the progressive corneal opacification in patients with EPCD [19].

Pinguecula was the most frequently found ophthalmoheliosis in this study (34\%). Most population studies in different parts of the world show its prevalence ranging from $11.3 \%$ to $90 \%$ of the adult population $[20,21]$. Pinguecula has been considered by some as the precursor or trigger of pterygium [16]. However, in our study none evolved into pterygium in the 10-year follow-up. Prevalence rates of pterygium in different population studies vary from $0.7 \%$ to $60 \%$, depending on the latitude and altitude of the region where they are studied. Permanent exposure to sunlight (UVR-B) close to the Equator is considered as the principal causal factor of pterygium. However, low preponderances have been reported in Beijing (3\%), intermediate values (around 12\%) in
Hawaii. Although pterygium has been reported as scant in the north and south of parallels 40 , there is a description of $5.9 \%$ pterygium prevalence in a community at 42 degrees latitude $\mathrm{N}$ of Spain. The prevalence of this disease around the world has been recently reviewed by Rezvan [22]. Our work shows a pterygium prevalence of $12 \%$ in a population located at the north west of Argentine Patagonia steppe (between $38^{\circ} 56^{\prime}-40^{\circ} 25^{\prime}$ of south latitude).

All these findings indicated that, although exposure to UVR-B could be a causal principal factor, it is far from being the only one. There are works that document the existence of pterygium related to certain ethnic groups (genetic predisposition) [2325], viral infections [26], and to defects in genes associated with DNA repair [27]. DNA is one of the greatest targets of UVR-B induced oxidative stress, and the modified DNA can result in genetic mutations [28]. There is consensus that UVR-B causes limbal focal defects, which are the main pathogenic factors in pterygium.

Our investigations show the existence of EPCD, pinguecula and pterygium south of parallel 30 , outside the "pterygium belt" described by Cameron [29]. We found a greater number and degree of EPCD severity in older men, but no difference in the prevalence of pinguecula and pterygium between men and women or between ages. As far as we know, this is the first study that evaluates the coexistence of these three degenerative diseases of the ocular surface.

Besides the individuals who only suffer from EPCD, or pinguecula, or pterygium, we identified patients with EPCD and pinguecula, others with EPCD and pterygium, a small number of individuals with pinguecula and pterygium and individuals with the three pathologies.

Even though there is a small cohort of pinguecula patients, the follow up of these patients for ten years showed that it is unlikely that pinguecula could be the beginning of pterygium. These diseases of the ocular surface can cause ocular discomfort, irritation, visual disturbance, and have cosmetic effects. They can also cause frustration in the affected individuals, given 
that there is no medical treatment available. Pinguecula is generally not treated, except for those cases which present recurrent inflammation, while the treatments of advanced cases of pterygium and EPCD, although they are different, consist of the extraction of the affected areas by surgery. As have been reviewed by Serra [30], different pterygium surgery techniques have been developed in the last decade. In cases of marked corneal opacity of patients with EPCD, penetrating or laminar queratosplasty, and the implant of an amniotic membrane have been used [31].

A greater knowledge of the genesis of these pathologies might contribute to preventing such potentially disabling diseases, taking into consideration that the cure is very complicated in marginal zones of the planet where there is high prevalence. Our investigations showed important prevalence of EPCD, pinguecula and pterygium in individuals that live in a semi-deserted region of the Argentine Patagonia, and coexistence of those diseases in many of them.

\section{Acknowledgement}

FONCYT PICT: 2016-0055.

\section{References}

1. Blumthaler M, Grbner J Huber M, Ambach W (1996) Measuring spectral and spatial variations of UVA and UVB skyradiance. Geophys Ret Lett 23(5): 547-550.

2. Sliney DH (2002) How light reaches the eye and its components. Int J Toxicol 21(6): 501-509.

3. Zigman S (1993) Ocular light damage. Photochem Photobiol 57(6): 1060-1068.

4. Estey T, Piatigorsky J, Lassen N, Vasiliou V (2007) ALDH3A1: a corneal crystalline with diverse functions. Exp Eye Res 84(1): 3-12.

5. Marchetti C, Sidahmed Adrar N, Collin F, Jore D, Gardès Albert M, et al. (2011) Melatonin protects PLPC liposomes and LDL towards radical induced oxidation. J Pineal Res 51(3): 286-296.

6. Kau HC, Tsai CC, Lee CF, Kao SC, Hsu WM, et al. (2006) Increased oxidative DNA damage, 8-hydroxydeoxy- guanosine, in human pterygium. Eye (Lond) 20(7): 826-831.

7. Bensasson RV, Land EJ, Truscott TG (1993) Excited states and free radicals in biology and medicine: Contributions from flash photolysis and pulse radiolysis. Oxford University Press, Oxford, UK.

8. Pattison DI, Davies MJ (2006) Actions of ultraviolet light on cellular structures (Review). EXS 96: 131-157.

9. Urrets Zavalía JA, Knoll EG, Maccio JP, Urrets Zavalía EA, Saad JA, et al. (2006) Climatic droplet keratopathy in the Argentine Patagonia. Am J Ophthalmol 141(4): 744-746.

10. Suarez MF, Correa L, Crim N, Espósito E, Monti R, et al. (2015) Climatic droplet keratopathy in Argentina: involvement of environmental agents in its genesis which would open the prospect for new therapeutic interventions. Biomed Res Int p. 9.

11. Serra HM, Holopainen JM, Beuerman R, Kaarniranta K, Suárez MF, et al. (2015) Climatic droplet keratopathy: an old disease in new clothes. Acta Ophthalmol 93(6): 496-504.

12. Cardenas Cantu E, Zavala J, Valenzuela J, Valdez Garcia JE (2016) Molecular Basis of Pterygium Development. Semin Ophthalmol 31(6): 567-583.
13. Norn MS (1979) Prevalence of pinguecula in Greenland and in Copenhagen, and its relation to pterygium and spheroid degeneration. Acta Ophthalmol (Copenh) 57(1): 96-105.

14. Forsius H, Eriksson A (1963) The incidence of pinguecuia and pterygium in indoor and outdoor workers. Klin Monbl Augenheilkd 142: 1021-1030.

15. Kim TH, Chun YS, Kim JC (2013) The pathologic characteristics of pingueculae on autofluorescence images. Korean J Ophthalmol 27(6): 416-420.

16. Hilgers JH (1960) Pterygium: its incidence, heredity and etiology. Am J Ophthalmol 50: 635-644.

17. Serra HM, Suarez MF, Esposito E, Urrets Zavalıa A (2014) Vitamin C functions in the cornea: Ultra-structural features in ascorbate deficiency. In: Preedy VR (Edition). The handbook of nutrition, diet and the eye. London, UK: Elsevier Inc Chapter 31: 311-320.

18. Marchitti SA, Chen Y, Thompson DC, Vasiliou V (2011) Ultraviolet radiation: cellular antioxidant response and the role of ocular Aldehyde dehydrogenase enzymes. Eye Contact Lens 37(4): 206-213.

19. Serra HM, Suárez MF, Urrets Zavalía JA (2017) Environmental proteinaceous corneal degeneration: A rare disease. In: "Rare diseases" Chapter: 31.

20. Asokan R, Venkatasubbu RS, Velumuri L, Lingam V, George R (2012) Prevalence and associated factors for pterygium and pinguecula in a South Indian population. Ophthalmic Physiol Opt 32(1): 39-44.

21. Norn MS (1982) Spheroid degeneration, pinguecula, and pterygium among Arabs in the Red Sea territory, Jordan. Acta Ophthalmol (Copenh) 60(6): 949-954.

22. Rezvan F, Khabazkhoob M, Hooshmand E, Yekta A, Saatchi M, et al. (2018) Prevalence and risk factors of pterygium: a systematic review and meta-analysis. Surv Ophthalmol 63(5): 719-735.

23. Huang TL, Hsu SY, Tsai RK, Sheu MM (2010) Etiology of ocular diseases in elderly Amis aborigines in Eastern Taiwan (The Amis Eye Study). Jpn J Ophthalmol 54(4): 266-271.

24. Shiroma H, Higa A, Sawaguchi S, Iwase A, Tomidokoro A, et al. (2009) Prevalence and risk factors of pterygium in a South-western island of Japan: The Kumejima Study. Am J Ophthalmol 148(5): 766-771.

25. West S, Munoz B (2009) Prevalence of pterygium in latinos: proyecto VER. Br J Ophthalmol 93(10): 1287-1290.

26. Detorakis ET, Spandidos DA (2009) Pathogenetic mechanisms and treatment options for ophthalmic pterygium: Trends and perspectives (Review). Int J Mol Med 23(4): 439-447.

27. Liu T, Liu Y, Xie L, He X, Bai J (2013) Progress in the pathogenesis of pterygium. Curr Eye Res 38(12): 1191-1197.

28. Cadet J, Douki T, Gasparutto D, Ravanat JL (2003) Oxidative damage to DNA: formation, measurement and biochemical features. Mutat Res 531(1-2): 5-23.

29. Cameron ME (1965) Pterygium throughout the World. Springfield, Charles C. Thomas.

30. Serra HM, Suarez MF, Maccio JP, Esposito E, Urrets Zavalía JA (2017) Pterygium: A complex and multifactorial ocular surface disease. A review on its pathogenic aspects. In: "Rare diseases".

31. Rao A, Sridhar U, Gupta AK (2008) Amniotic membrane transplant with superficial keratectomy in superficial corneal degenerations: efficacy in a rural population of north India. Indian J Ophthalmol 56(4): 297-302. 
This work is licensed under Creative Commons Attribution 4.0 License DOI: 10.19080/JOJO.2019.07.555711

\section{Your next submission with Juniper Publishers will reach you the below assets}

- Quality Editorial service

- Swift Peer Review

- Reprints availability

- E-prints Service

- Manuscript Podcast for convenient understanding

- Global attainment for your research

- Manuscript accessibility in different formats

( Pdf, E-pub, Full Text, Audio)

- Unceasing customer service

Track the below URL for one-step submission

https://juniperpublishers.com/online-submission.php 